\title{
LATVIAN FAMILY PHYSICIANS’ EXPERIENCE AND ATTITUDE IN DIAGNOSING AND MANAGING DEPRESSION
}

\author{
Vineta Viktorija Vinogradova ${ }^{1, \#}$, Jelena Vrubḷevska ${ }^{2}$, and Elmārs Rancāns ${ }^{2}$ \\ ${ }^{1}$ Faculty of Postgraduate Education, Rīga Stradiṇš University, 16 Dzirciema Str., Rīga, LV-1007, LATVIA \\ 2 Department of Psychiatry and Narcology, Rīga Stradinš University, 2 Tvaika Str., 2, Rīga, LV-1005, LATVIA \\ \# Corresponding author, vineta.vinogradova@gmail.com
}

Communicated by Modra Murovska

\begin{abstract}
Depression is among the most common mental disorders in primary care. Despite high prevalence rates it remains to be under-diagnosed in primary care settings over the world. This study was aimed to identify Latvian family physicians' (FPs) experience and attitude in diagnosing and managing depression. It was carried out within the framework of the National Research Programme BIOMEDICINE 2014-2017. After educational seminars on diagnosing and managing depression, FPs were asked to complete a structured questionnaire. In total 216 respondents were recruited. Most of the doctors, or $72.2 \%(n=156)$, agreed with the statement that patients with depression use primary care facilities more often than other patients. More than a half of physicians, or $66.3 \%(n=143)$ quite often asked their patients about their psycho-emotional status and $65.7 \%(n=142)$ of clinicians thought that they can successfully assess a patient's psychoemotional status and possible mental disorders. The majority, or $91.6 \%(n=198)$, supposed that routine screening for depression is necessary in Latvia. Despite the fact that a significant number, or $62.6 \%(n=135)$ of FPs thought that their practice was well suitable for the treatment of depressive patients, half of the respondents, or $50.9 \%(n=110)$, assessed their ability to build a trustful contact and to motivate patients for treatment as moderate. Although FPs acknowledged the importance and necessity to treat depression, current knowledge and management approaches were far from optimal. This justifies the need to provide specific training programmes for FPs.

Key words: general practitioners, primary care, major depressive disorder, treatment, opinion.
\end{abstract}

\section{INTRODUCTION}

On average one in five adults worldwide experienced a common mental disorder during the past 12 months. Mood disorders, such as dysthymia, cyclothymia, bipolar affective disorder and major depression, constitute the second most prevalent class of mental disorders (Steel et al., 2014). Major depressive disorder, in particular, is the most frequent mood disorder in the European population (Alonso et al., 2004). The proportion of the global population with depression has been estimated at $4.4 \%$ (Anonymous, 2017). The point prevalence of depression in the general population of Latvia is estimated to be $6.7 \%$ (Rancans et al., 2014), and the 12-month prevalence of major depressive disorder is $7.9 \%$ (Vrublevska et al., 2017). The number of people suffering from major depressive disorder increased by $17.8 \%$ between 2005 and 2015, due to the growth of the global population (Vos et al., 2016). According to the World Health Organization depression nowadays is classified as the largest contributor to non-fatal health loss: $7.5 \%$ of all years lost due to disability (Anonymous, 2017). The depressive disorder is also associated with considerable impairment of quality of life, affecting patients both mentally and physically (Andriopoulos et al., 2013). Moreover, people with major depression have an increased chance of dying earlier (Cuijpers et al., 2013). Depression is one of the most economically burdensome diseases in the world. For example, depression results in almost 400 million disability days per year in the US. The economic burden, composed of indirect workplace costs, direct medical costs and suiciderelated mortality cost, in US reached $\$ 210.5$ billion in 2010 (Greenberg et al., 2015). Although there is available effec- 
tive treatment for this disease, less than a half of the affected people are being treated in conformity with the existing guidelines in the primary care level (Puyat et al., 2016; Trautman and Beesdo-Baum, 2017). A significant number of the patients suffering from depression are managed in primary care settings: in the US over a half of the eight million ambulatory care visits due to depression each year are to a primary care practitioner (Bishop et al., 2016). Unfortunately, major depressive disorder remains significantly underdiagnosed in the primary care environment in Latvia. Data of the National Health Service show that in 2016 family physicians saw only 5132 unique patients with a diagnosis of mood disorder (Šica et al. 2017), although the study within the National Research Programme BIOMEDICINE 2014-2017 showed that major depression is present in $10.2 \%$ of primary care patients (or approximately 70000 patients nationwide) visiting a physician for medical reasons (Rancans et al., 2018). Obstacles to precise diagnostics and effective therapy of patients with depression in primary care settings might include a lack of resources, imprecise assessment or lack of training in effective communication with people, suffering from mental diseases. Previous qualitative study found that a large subgroup of depression patients presented to primary care with solely somatic complaints, FPs often did not recognise depression in somatically presenting patients until several consultations had passed without resolution of the somatic complaint, and doctors had problems in asking their patients about the psycho-emotional state (Leff et al., 2017). This study is aimed to assess and analyse Latvian family physician's attitude and personal experience in the field of diagnosing and managing depression.

\section{MATERIALS AND METHODS}

Within the framework of the National Research Programme BIOMEDICINE 2014-2017, a team of researchers developed a depression diagnostic and treatment algorithm for use in primary care settings and a specific training module for family physicians to facilitate recognition and management of depression. In October-December 2016, throughout the territory of Latvia ten "Depression School" seminars for FPs were conducted. At the seminar general practitioners were asked to complete a structured questionnaire regarding their experience in diagnosing and managing depression.

Study design. A descriptive cross-sectional study was carried out. All participating family practitioners who attended the training module, regardless of the FP's experience in diagnosing and managing depression at their practice, were offered to complete the questionnaire. The exclusion criteria were: family physicians who refused to participate in the study and participants who do not practice as a family physician.

Assessment tool. The structured questionnaire developed by the team of researchers who participated in the training programme contained questions about general information and demographics (gender, age, years of practical experi- ence, workplace) and the following questions, regarding practical experience in diagnosing and managing depression: Do you agree that depression is a serious health problem among people in Latvia? Do you think that people who are suffering from depression use health services more often than other patients? Do you agree that it is important for a family physician to ask about the psycho-emotional state of the patient? How often do you ask your patients about their psycho-emotional state? In your opinion, to what extent could conversation about a patient's psycho-emotional status be considered as unacceptable interference in the patient's private life? How do you assess your communication with patients about their psycho-emotional state? With patients of which gender do you find it easier to discuss issues related to the psycho-emotional state? After the conversation with the patient, how well can you assess his or her psycho-emotional status and possible disorders? Do you think that it is necessary to introduce screening for the identification of depression in Latvia? Do you use the Patient Health Questionnaire (PHQ -9) to assess the risk of depression among your patients in your daily practice? What are your usual tactics when you suspect depression in your patient? How well is your FP practice suitable to be involved in the treatment of patients with depressive symptoms? In your opinion, how well can you motivate your patient for treatment? Respondents were offered to choose one or several most appropriate answers from the proposed variants.

Statistical analysis. The statistical analysis of the data was performed using the IBM SPSS (Version 23) software package (IBM Corporation, New York, USA). The assessment of normality of the data was performed using histograms and Kolmogorov-Smirnov test. Descriptive statistics included frequencies, shown in absolute numbers and percentages for categorical variables with median and interquartile range for numerical variables. The independent sample Kruskal-Wallis test and the chi-square test were used to assess the associations between variables. The significance level A (alfa) $=0.05$ was used.

Ethics. The research was conducted in accordance with the Declaration of Helsinki and its subsequent amendments. Ethical permission was granted by the Rìga Stradiňš University Ethics Committee.

\section{RESULTS}

Demographic data. In total 273 participants attended "Depression school" seminars. Although, the training module was originally developed for family physicians, clinicians of other specialties also were interested in topic and attended seminars. Thus, the total number of participants included FPs under contract with the National Health Service ( 210 or $15.2 \%$ of 1382 Latvian FPs), and privately practising family physicians, nurses, medical assistants and clinicians of other specialties. The overall response rate was 82.05\%: 224 clinicians of 273 participants of the educational seminars completed the questionnaires. Eight completed questionnaires did not match the inclusion criteria of 
MAIN CHARACTERISTICS OF THE SAMPLE GROUP

\begin{tabular}{lll}
\hline Characteristics & $\mathrm{n}(\%)$ \\
\hline Male & & $23(10.6 \%)$ \\
Female & $189(87.5 \%)$ \\
Gender not mentioned & & $4(1.9 \%)$ \\
Workplace: & & $193(89.4 \%)$ \\
& Private practice & $19(8.8 \%)$ \\
& Outpatient clinic & $1(0.5 \%)$ \\
& Hospital & $2(0.9 \%)$ \\
& Specialised medicine & \\
& centre & \\
Median age: 55.0 (IQR:13) years.
\end{tabular}

$\overline{\mathrm{IQR} \text {, interquartile range }}$

the study: these clinicians did not practice as family physicians. In total 216 questionnaires were analysed. Most of the respondents $87.5 \%(\mathrm{n}=189)$ were females and only $10.6 \%(\mathrm{n}=23)$ of recruited general practitioners were males, $1.9 \%(n=4)$ respondents did not mention their gender. Half of the doctors were younger than 55 years old. Median practical experience of the recruited FP's was 29.0 (IQR : 15) years. Among trained doctors, 23.8\% had their practice in Rìga, $25.7 \%$ in other large cities and $50.5 \%$ in other areas, e.g. small cities, rural communities (Table 1).

Opinion on depression as a challenge for the healthcare system. Most of the doctors, or $76.4 \%(\mathrm{n}=165)$ absolutely agreed that depression is a serious disease and $81.9 \%(\mathrm{n}=$ 177) of FPs admitted that they often meet patients suffering depression. The majority, or $72.2 \%(n=156)$ of doctors noticed that patients with depression use primary care more often than other patients.

Conversation about patients' psychological issues and recognising depression. A large proportion of doctors, or $75.9 \%(n=164)$, recognised that it was essentially important to ask patients about their psycho-emotional state, even if the purpose of visit of the patient was related to somatic complaints. However, relatively many physicians - $74.1 \%$ $(n=160)$ regarded that conversation about a patient's psycho-emotional status in varying degrees could be considered as unacceptable interference to the patient's private life, and only $23.6 \%(n=51)$ of doctors were sure that such an interest from the medical person could not be considered as interference. More than a half of the doctors, or $66.3 \%$ $(n=143)$, quite often asked their patients about their psycho-emotional status during the visits. There was no statistically significant correlation between the age of the FPs and the frequency of asking patients about their emotional state $(p=0.63)$. We also did not found a statistically significant association between gender of the doctor and preferable gender of the patient to ask about psycho-emotional issues $(p=0.53)$, but nevertheless, $87.7 \%$ of female doctors preferred to speak about psycho-emotional status with patients of female gender. More than one half of respondents, or $65.7 \%(\mathrm{n}=142)$, thought that they could assess a patient's psycho-emotional status and possible disorders quite well after discussion about his or her emotional problems, but about half of the FPs or $52.3 \%(n=113)$ critically assessed their usual contact with depressive patients and describe it as moderated or quite poor.

Screening for depression and usage of Patient Health Questionnaire (PHQ-9). Nearly a half, or 49.1\% $(\mathrm{n}=106)$, of the physicians never used the PHQ-9 to assess the risk of depression in their patients. Many doctors $(91.6 \%, \mathrm{n}=198)$ considered that screening for depression is necessary in Latvia and $86.1 \%(n=186)$ support the idea of introduction of routine screening into family physicians' practices.

Experience in treatment and managing depression. More than one half or $62.6 \%(n=135)$ of FPs considered that their practice was well suitable for the treatment of depressive patients, but half of the respondents $(50.9 \%, \mathrm{n}=110)$, assessed their ability to motivate patients for treatment as moderate. The three most commonly reported tactics among physicians after suspecting depression were discussion with the patients about their existing problems and situation, prescribing necessary medicines, and referral to a psychiatrist (Fig. 1).

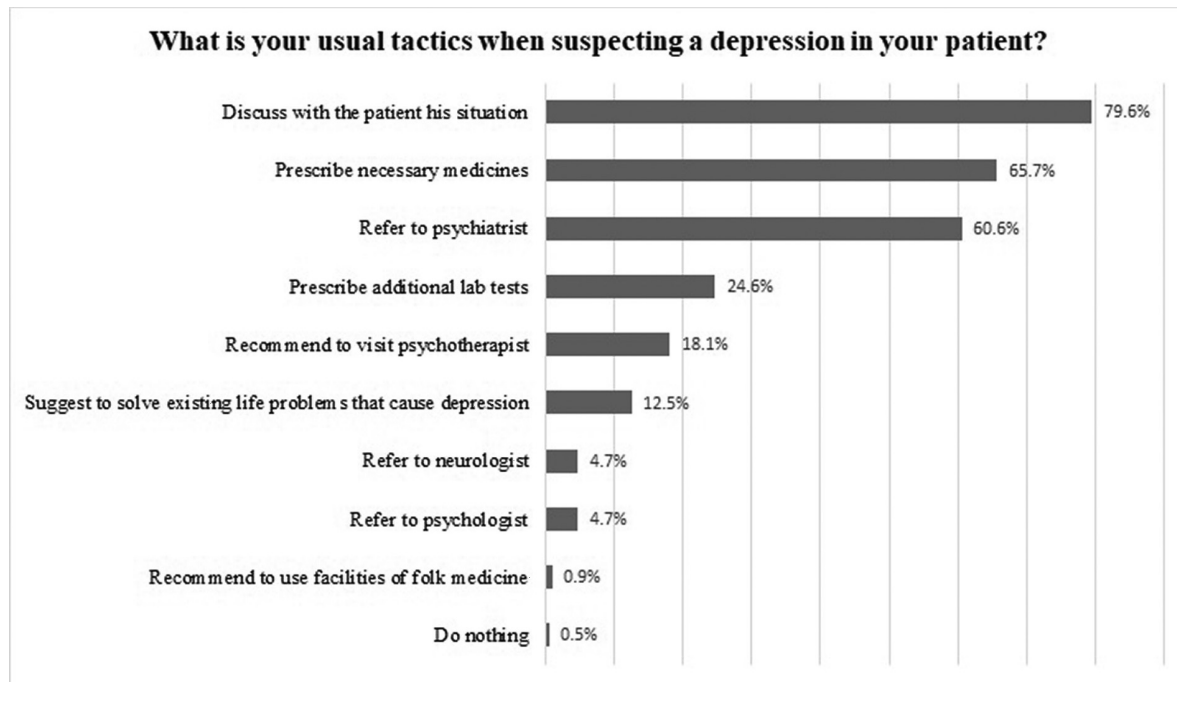

Fig. 1. Usual tactics of family physicians when suspecting a depression. 


\section{DISCUSSION}

Opinion on depression as a challenge for healthcare system. According to the present study, prevalence of depression in Latvian primary care settings is similar to the prevalence rates in primary care services in other countries, which range between 5 and 10\% (Katon and Schulberg, 1992; Craven and Bland, 2013) and is estimated to be $10.2 \%$ (Rancans et al., 2018). A cross-sectional study covering 226 FP's practices across the US reported that depression was diagnosed in nearly one fifth of all patients (Ornstein et al., 2013). Most of the doctors recruited in our study confirmed that they often are visited by patients suffering with depression symptoms. Latvian FPs also noticed that depressive patients use primary care services more often than non-depressive patients, which was also reported previously (Shvartzman et al., 2005) in Israel. In a 12-month study of prevalence of depression in the general population of Latvia, six or more patient visits to any healthcare service in one year was associated with 2.0-fold increased odds of having major depression. Moreover, patients with three or more somatic disorders had 2.0 fold greater probability of having major depression (Vrublevska et al., 2017). A systematic review by Luppa et al. (2012) reported that mean annual number of family physician visits ranged from 3 to 10 visits for depressive patients compared to 3 to 5 visits for persons not suffering depression, which is logically related to the greater healthcare related costs. A recently published cohort study on the effects of depression on health care utilisation and costs estimated mean total costs per six-month period as USD 8144 for patients with depression compared to USD 3137 for patients without depression (Bock et al., 2014). That study analysed samples of multimorbid elderly patients, which is rather relevant to usual family physician practice. Studies suggest that almost two-thirds of all patients in FPs practices have at least one or more chronic diseases (Ornstein et al., 2013). Prevalence of major depressive disorder is 3 to 7 times greater in persons with a chronic diseases, like stroke, heart disease, diabetes, cancer, osteoporosis and rheumatoid arthritis (Moussavi and Chatterji, 2007; Clarke and Currie, 2009; Vrublevska et al., 2017). Therefore, it is essentially important especially in primary care services to diagnose depression timely and treat this condition effectively. In our study 75.9\% of doctors understood that it is important to ask patients about their psycho-emotional state, even if the primary cause of the patient's visit was a somatic issue; most of the doctors also often asked their patients about psycho-emotional status.

Opinion on routine screening for depression. Although there is some evidence that doubts the effectiveness of screening for depression (Bland and Streiner, 2013), Latvian family physicians consider it to be necessary in Latvia. This statement can be justified by the recommendations of the US Preventive Services Task Force, which reported that routine screening in primary care settings can facilitate improvement of the diagnosis rates of depression in adults (Siu et al., 2016). Screening would be particularly meaning- ful in specific groups of patients. The PHQ-9 validation study in the nationwide primary care population identified risk factors for having depression, like occasional smoking, multiple somatic diseases, perception of personal health status as being below average. This information was used to develop diagnostic and treatment algorithms for depression in primary care in Latvia (Vrublevska et al., 2017; Rancans et al., 2018). Other studies suggested that patients with a Systematic COronary Risk Evaluation (SCORE) 10\% could benefit from screening and early treatment of depression to potentially delay its development and improve the prognosis of cardiovascular disease (Ivanovs et al., 2018). However, while the doctors in our study were ready to introduce routine screening of depression in their practices, the US Preventive Services Task Force recommended against routine screening unless "staff-assisted depression care supports are in place to assure accurate diagnosis, effective treatment and follow-up".

Usage of diagnostic instruments. The PHQ-9 (and PHQ-2) screener was developed for use in primary care services and is the only questionnaire that has been tested in a nationwide primary care population in Latvia. Latvian and Russian versions of the PHQ-9 and PHQ-2 have shown moderate psychometric properties for screening for major depression in general practice with a recommended cut-off score of 8 or greater for the PHQ- 9 and 2 or greater for the PHQ-2 (Rancans et al., 2018). Nevertheless, nearly $50 \%$ of physicians never have used the PHQ-9 to assess the risk of depression in their patients. Somewhat similar findings were reported in a Canadian qualitative study that analysed individual interviews with family physicians, internists, and nurse practitioners (Baik et al., 2010). The clinicians involved in the Canadian study reported occasional use of depression instruments. The most commonly reported way of using such instruments was to promote patients' acceptance of the psychiatric diagnosis when resistance to the diagnosis was observed.

The most promising reported ways of facilitating wide usage of PHQ-2 and PHQ-9 include:

- Providing primary care practices with an additional number of medical assistants, who could undertake the duty of performing depression screening among patients. For example, a team-based primary care delivery model called "ambulatory process excellence" (APEX), piloted by the University of Colorado appeared to be effective in improving the PHQ-9 completion rate. The model employed five medical assistants supporting two physicians: they were responsible, among other manipulations, for performing depression screening with PHQ-2 and PHQ-9 before the physician entered the exam room (Smith et al., 2017).

- Other tactics could include developing a clearly stated paper or computer-assisted algorithm of depression screening and incorporation of depression screening and management tools in the electronic system of patients' health records, including a clinical decision support sys- 
tem for depression care management: e.g. guidelines for treatment, follow-up scheduling and contact-information of local mental health services (Bajracharya et al., 2016; Honigfeld et al.,2017). Development of a registry of screened patients could also be effective (Yang et al., 2018).

- Reimbursement incentive for screening has to be available for primary care providers (Lynch et al., 2016).

- Specifically developed education companies and training-programmes about the implementation of PHQ-9 depression screening tool among family physicians practice can to be effective (Tan, 2018).

Further investigations are necessary to understand factors that prevent wide usage of PHQ-9 in the Latvian population and choose the most appropriate way of resolving this problem.

Experience in diagnosing depression. It is considered that two-thirds of patients with depression remain undiagnosed in primary care services (Ani et al., 2008). Interestingly, physicians in our study evaluated their ability to assess psycho-emotional disorders as quite good. Similarly, in a focus group study conducted in the Netherlands, the participants did not considered identification of depression as problematic in their experience (Van Rijswijk et al., 2009). However, accordingly to other studies, accuracy of family physicians in diagnosing depression is relatively low: general practitioner's (GP) sensitivity, compared with the Hospital Anxiety and depression scale (HADS), is 33\% (Kendrick et al., 2005). Primary care specialists in another study successfully diagnosed depression in only $31.0 \%$ of participants meeting the PHQ-9 criteria for depression. (Ani et al., 2008). The process of diagnosing depression results in a number of challenges, many of which arise because of inappropriate doctor-patient communication. Latvian general practitioners assessed their usual contact with depressive patients as moderate or quite bad. Similarly, participants in a qualitative study from the Netherlands were positive about their communication skills in general, but experienced limited specific skills and knowledge in communicating with patients with mental health problems (Van Rijswijk et al., 2009). Moreover, depressive symptoms were reported to be associated with perceived deficits in doctor-patient communication in patients with chronic coronary heart disease (Schenker et al., 2009). An obstacle for productive doctor-patient communication may be dysfunctional belief of FPs that conversation about a patient's psycho-emotional status in varying degrees could be considered an unacceptable interference in the patient's private life, as found in our study. This might occur because elderly doctors brought up in the conservative and emotionally-closed society of the USSR prefer to avoid discussing psycho-emotional aspects of diseases. In order to test this hypothesis associations between age of clinicians and their frequency of asking patients about psychological issues were analysed. No statistically significant association was found, which allow us to conclude that age of the physician does not affect the fre- quency of discussing psychological issues with patients in Latvian primary care settings. We also checked the statement that doctor's gender can affect the doctor-patient interaction (Bertakis, 2009). Female physicians were found to spend a longer time with female patients (Hall et al., 1994). In our study, there was no association between gender of the doctor and preferable gender of the patient to discuss possible psycho-emotional problems. However, $87.7 \%$ of female doctors preferred to speak about psycho-emotional state with patients of female gender. Limitations of our study include a significantly smaller group of male physicians, which might have affected the results. For more precise statistical analysis equal proportions of female and malephysicians are advisable.

Experience in managing depression. Effective management of depression requires patient education about treatment options and possible side-effects, initiation of evidence-based pharmacotherapy or psychotherapy and consistent follow-ups. Almost 30 million people in the US receive prescriptions for antidepressants each year. Unfortunately, many patients stop medication prematurely because of side effects or other concerns and do not contact with their primary care provider to change treatment (Unützer and Park, 2012). Latvian general practitioners also assess their ability to motivate patients for treatment as moderate.

The most popular self-reported tactics among physicians if suspecting depression were:

Discussion with patients about their situation and existing problems. FPs in other countries also considered problem solving therapy as beneficial interventions, suitable in family practice, but point out a deficit in their skills to apply such techniques (Van Rijswijk et al., 2009). Many primary care physicians have minimal training in psychotherapy, which raises concerns of the effectiveness of such interventions.

Prescribing necessary medicines. Such tactics are supported by the modern evidence-based approach to the disease: effective treatment of depression in adults generally includes antidepressants alone or in combination with psychotherapy (Siu et al., 2016).

Referral to a psychiatrist. Such an approach appears to be one of the most popular among Latvian family physicians. However, there are recommendations stating that patients should be referred to a psychiatrist only under conditions of comorbid medical conditions, no improvement after one or two trials of medication, substance abuse, psychotic symptoms, risk of suicide or pregnancy ( $\mathrm{Ng}$ et al., 2017).

Prescribing additional tests. The reason for doctors prescribing additional tests was explained in the recent qualitative study. Even in cases when FPs suspected that their patient suffered from depression, difficulties in understanding the cause of the somatic complaints and in enhancing patients' acceptance of the psychiatric diagnosis forced FPs to perform physical examinations before establishing a diagnosis. 
FPs in this study reported, that the negative results of additional tests were some kind of a 'proof' of the symptoms' of psychiatric origin (Leff et al., 2017).

Referral to psychotherapist. Psychotherapy has been proven to be as effective as antidepressants for patients with mild to moderate major depression (Bortolotti et al., 2008). However, this option is not as popular as prescribing medicines among Latvian physicians. Similar findings were observed in a French study (Verdoux et al. 2014), in which one of four family physicians reported prescribing psychological therapy alone in mild-to-moderate depression. GPs that suggested their patients to try psychotherapy were more likely to have a personal history of psychotherapy. This finding suggests that educational programmes are required for providing evidence-based decision-making skills regarding psychological therapy.

There are several future prospects in development of depression diagnostics and management: additional financial and human resources could be used to establish one of the most effective and best-studied collaborative care models, the so-called "Collaborative Care for Depression" (Archer et al., 2012). Within this model, primary care providers work closely in a collaboration with mental health specialists in the process of managing patients with depression. Such intervention has demonstrated improved remission rates.

Although, the present study has reached its aims, the results in this report must be considered in the context of some limitations:

Sample size. This study included a sample covered all Latvian regions and was conducted in urban and rural settlements, but only $15.2 \%$ of 1382 FP's in contract with the National Health Service were recruited.

Selection bias. Application to the training seminar was voluntary and most probably FPs with larger interest and confidence in treating depression participated, causing the socalled "healthy worker effect".

Respondent bias. Self-reported data could be critically assessed due to possible recall bias, when respondents cannot precisely and accurately report their experience (Sedgwick, 2012).

Study design. In a cross sectional study, all the data are obtained at a single point of time-data on each family physician were recorded only once, therefore, only an association, and not causation, can be deduced from this study.

\section{ACKNOWLEDGEMENTS}

The authors acknowledge the National Research Programme BIOMEDICINE (2014-2017) for funding this study and Ministry of Education and Sciences, Republic of Latvia.

\section{REFERENCES}

Alonso, J., Angermeyer, M. C., Bernert, S., Bruffaerts, R., Brugha, T. S., Bryson, H., Vollebergh, W. A. M. (2004). Prevalence of mental disorders in Europe: Results from the European Study of the Epidemiology of Mental Disorders (ESEMeD) project. Acta Psychiatr. Scandin., 109 (420), 21-27.

Andriopoulos, P., Lotti-Lykousa, M., Pappa, E., Papadopoulos, A. A., Niakas, D. (2013). Depression, quality of life and primary care: A cross-sectional study. J. Epidemiol. Global Health, 3 (4), 245-252.

Ani, C., Bazargan, M., Hindman, D., Bell, D., Farooq, M. A., Akhanjee, L., Rodriguez, M. (2008). Depression symptomatology and diagnosis: Discordance between patients and physicians in primary care settings. BMC Fam. Pract., 9, 1-9.

Anonymous (2017). Depression and other common mental disorders: Global health estimates. World Health Organization, 1-24. Available from: https://www.who.int/mental_health/management/depression/prevalence_global_health_estimates/en/(accessed 20.01.2019).

Archer, J., Bower, P., Gilbody, S., Lovell, K., Richards, D., Gask, L., Dickens, C., Coventry, P. (2012). Collaborative care for depression and anxiety problems. Cochrane Database Syst. Rev., 10, CD006525

Baik, S.-Y., Gonzales, J. J., Bowers, B. J., Anthony, J. S., Tidjani, B., Susman, J. L. (2010). Reinvention of depression instruments by primary care clinicians. Ann. Fam. Med., 8 (3), 224-230.

Bajracharya, P., Summers, L., Amatya, A. K., DeBlieck, C. (2016). Implementation of a depression screening protocol and tools to improve screening for depression in patients with diabetes in the primary care setting. $J$. Nurse Pract., 12 (10), 690-696.

Bishop, T. F., Ramsay, P. P., Casalino, L. P., Bao, Y., Pincus, H. A. (2016) Care management processes used less often for depression than for other chronic conditions in US primary care practices. Health Affairs, 35 (3), 394-400.

Bertakis, K. D. (2009). The influence of gender on the doctor-patient interaction. Patient Ed. Couns., 76 (3), 356-360.

Bock, J.-O., Luppa, M., Brettschneider, C., Riedel-Heller, S., Bickel, H., Fuchs, A., König, H.-H. (2014). Impact of depression on health care utilization and costs among multimorbid patients: Results from the MultiCare Cohort Study. PLoS ONE, 9 (3), e91973.

Bortolotti, B., Menchetti, M., Bellini, F., Montaguti, M. B., Berardi, D. (2008). Psychological interventions for major depression in primary care: A meta-analytic review of randomized controlled trials. Gen. Hospit. Psychiatry, 30 (4), 293-302.

Clarke, D. M., Currie, K. C. (2009). Depression, anxiety and their relationship with chronic diseases: A review of the epidemiology, risk and treatment evidence. Med. J. Austral., 190 (7), 54-60.

Craven, M. A., Bland, R. (2013). Depression in primary care: Current and future challenges. Can. J. Psychiatry, 58 (8), 442-448.

Cuijpers, P., Vogelzangs, N., Twisk, J., Kleiboer, A., Li, J., Penninx, B. W (2013). Differential mortality rates in major and subthreshold depression: Meta-analysis of studies that measured both. Brit. J. Psychiatry, 202 (1), 22-27.

Dumesnil, H., Cortaredona, S., Verdoux, H., Sebbah, R., Paraponaris, A., Verger, P. (2012). General practitioners' choices and their determinants when starting treatment for major depression: A cross sectional, randomized case-vignette survey. PLOS ONE, 7 (12), e52429.

Greenberg, P. E., Fournier, A.-A., Sisitsky, T., Pike, C. T., Kessler, R. C. (2015). The Economic burden of adults with major depressive disorder in the United States (2005 and 2010). J. Clin. Psychiatry, 76 (2), 155-162.

Hall, J. A., Irish, J. T., Roter, D. L., Ehrlich, C. M., Miller, L. H. (1994). Gender in medical encounters: An analysis of physician and patient communication in a primary care setting. Health Psychology, 13 (5), 384-392.

Honigfeld, L., Macary, S. J., Grasso, D. J. (2017). A clinical care algorithmic toolkit for promoting screening and next-level assessment of pediatric depression and anxiety in primary care. J. Pediatric Health Care, 31 (3), e15-e23. 
Ivanovs, R., Kivite, A., Ziedonis, D., Mintale, I., Vrublevska, J., Rancans, E. (2018). Association of depression and anxiety with the 10-year risk of cardiovascular mortality in a primary care population of Latvia using the SCORE system. Frontiers in Psychiatry, 9, 276

Katon, W., Schulberg, H. (1992). Epidemiology of depression in primary care. Gen. Hospit. Psychiatry, 14 (4), 237-247.

Kendrick, T., King, F., Albertella, L., Smith. (2005). GP treatment decisions for patients with depression: An observational study. Brit. J. Gen. Pract., 55 (513), 280-286.

Leff, M. S., Vrubḷevska, J., Lūse, A., Rancāns, E. (2017). Latvian family physicians' experience diagnosing depression in somatically presenting depression patients: A qualitative study. Eur. J. Gen. Pract., 23 (1), 91-97.

Lynch, J. R., Berg, S. T., Manna, J., Schade, C. P. (2016). Making a dent in undiagnosed and untreated depression among older West Virginians. West Virginia Med. J., 112 (3), 60-66.

Luppa, M., Sikorski, C., Motzek, T., Konnopka, A., König, H., Riedel-Heller, S. (2012). Health service utilization and costs of depression in late life: A systematic review. Curr. Pharmaceut. Design, 18 (36), 5936-5957.

Moussavi, S., Chatterji, S. (2007). Depression, chronic diseases, and decrements in health: Results from the World Health Surveys. Lancet, 370, $851-858$.

Ng, C. W. M., How, C. H., Ng, Y. P. (2017). Managing depression in primary care. Singapore Med. J., 58 (8), 459-466.

Ornstein, S. M., Nietert, P. J., Jenkins, R. G., Litvin, C. B. (2013). The prevalence of chronic diseases and multimorbidity in primary care practice: A PPRNet Report. J. Amer. Board Fam. Med., 26 (5), 518-524.

Puyat, J. H., Kazanjian, A., Goldner, E. M., Wong, H. (2016). How often do individuals with major depression receive minimally adequate treatment? A population-based, data linkage study. Can. J. Psychiatry, 61 (7), 394-404

Rancans, E., Vrublevska, J., Snikere, S., Koroleva, I., Trapencieris, M. (2014). The point prevalence of depression and associated sociodemographic correlates in the general population of Latvia. J. Affect. Disord., 156, 104-110.

Rancans, E., Trapencieris, M., Ivanovs, R., Vrublevska, J. (2018). Validity of the PHQ-9 and PHQ-2 to screen for depression in nationwide primary care population in Latvia. Ann. Gen. Psychiatry, 17 (1), 33.

Schenker, Y., Stewart, A., Na, B., Whooley, M. A. (2009). Depressive symptoms and perceived doctor-patient communication in the heart and soul study. J. Gen. Intern. Med., 24 (5), 550-556.

Scott, C., Tacchi, M. J., Jones, R., Scott, J. (1997). Acute and one-year outcome of a randomised controlled trial of brief cognitive therapy for major depressive disorder in primary care. Brit. J. Psychiatry, 171, 131-134.

Shvartzman, P., Weiner, Z., Vardy, D., Friger, M., Sherf, M., Biderman, A. (2005). Health services utilization by depressive patients identified by the
MINI questionnaire in a primary care setting. Scand. J. Primary Health Care, 23 (1), 18-25.

Sedgwick, P. (2012). What is recall bias? BMJ, 344 (7858), 1-2.

Šica, K., Pulmanis, T., Taube, M. (2017). Psihiskā veselība Latvijā 2016. gadā [Mental health in Latvia in 2016]. Slimību kontroles un profilakses centrs, Rīga. 57 lpp. (in Latvian).

Siu, A. L., Bibbins-Domingo, K., Grossman, D. C., Baumann, L. C., Davidson, K. W., Ebell, M., Pignone, M. P. (2016). Screening for depression in adults. Jama, 315 (4), 380.

Smith, P. C., Brown Levey, S. M., Lyon, C. (2017). Evaluating transformation with available resources: The influence of APEX on depression screening. Fam. Syst. Health, 35 (2), 238-247.

Steel, Z., Marnane, C., Iranpour, C., Chey, T., Jackson, J. W., Patel, V., Silove, D. (2014). The global prevalence of common mental disorders: A systematic review and meta-analysis 1980-2013. Int. J. Epidemiol., 43 (2), 476-493.

Tan, M. C. (2018). Depression screening in Asian Americans: A quality improvement project (Order No. 10811726). Available from ProQuest Dissertations \& Theses Global: The Sciences and Engineering Collection. (2043390921).

Trautman, S., Beesdo-Baum, K. (2017). Behandlung depressiver Störungen in der primärärztlichen Versorgung. Deutsches Arzteblatt International, 114 (43), 721-728

Unützer, J., Park, M. (2012). Strategies to improve the management of depression in primary care. Primary Care Clin. Off. Pract., 39 (2), 415-431.

Van Rijswijk, E., Van Hout, H., Van De Lisdonk, E., Zitman, F., Van Weel, C. (2009). Barriers in recognising, diagnosing and managing depressive and anxiety disorders as experienced by Family Physicians; A focus group study. BMC Fam. Pract., 10, 1-7.

Verdoux, H., Cortaredona, S., Dumesnil, H., Sebbah, R., Verger, P. (2014). Psychotherapy for depression in primary care: A panel survey of general practitioners' opinion and prescribing practice. Soc. Psychiatry Psychiatric Epidemiol., 49 (1), 59-68.

Vos, T., Allen, C., Arora, M., Barber, R. M., Brown, A., Carter, A., Zuhlke, L. J. (2016). Global, regional, and national incidence, prevalence, and years lived with disability for 310 diseases and injuries, 1990-2015: A systematic analysis for the Global Burden of Disease Study 2015. The Lancet, 388 (10053), 1545-1602.

Vrublevska, J., Trapencieris, M., Snikere, S., Grinberga, D., Velika, B., Pudule, I., Rancans, E. (2017). The 12-month prevalence of depression and health care utilization in the general population of Latvia. J. Affect. Disord., 210, 204-210.

Yang, M., Loeb, D. F., Sprowell, A. J., Trinkley, K. E. (2019). Design and implementation of a Depression Registry for Primary Care. Amer. J. Med. Qual., 34 (1), 59-66.

Received 1 November 2018

Accepted in the final form 3 January 2019

\section{GIMENES ĀRSTU ATTIEKSME UN PIEREDZE DEPRESIJAS DIAGNOSTIKĀ UN APRŪPĒ}

Depresija ir viena no biežākajām sastopamajām garīgajām slimībām primārajā aprūpē. Neraugoties uz tās plašu izplatību, depresija bieži vien paliek nediagnosticēta veselības primārās aprūpes līmenī. Šì pētījuma mērkis bija noteikt ğimenes ārstu attieksmi un pieredzi depresijas diagnostikā un ārstēšanā Latvijas primārās aprūpes iestādēs. Pētījums tika īstenots Valsts pētījumu programmas BIOMEDICINE $2014-2017$ ietvaros. Pēc izglītojošiem semināriem par depresijas diagnostiku un aprūpi ǵimenes ārstiem tika piedāvāts aizpildīt strukturētu anketu. Kopumā pētījumā piedalījās 216 ǵimenes ārsti. Vairākums ārstu, vai 72,2\% (n=156) ǵimenes ārstu piekrīt apgalvojumam, ka pacienti ar depresiju izmanto primārās veselības aprūpes pakalpojumus biežāk nekā citi pacienti. Vairāk kā puse, jeb 66,3\% (n = 143) ârstu diezgan bieži vizīšu laikā jautā saviem pacientiem par viņu psihoemocionālo stāvokli, un 65.7\% (n=142) ārstu, domā, ka parasti pēc sarunas ar pacientu veiksmīgi spēj novērtēt cilvēka psihoemocionālo stāvokli un iespējamos traucējumus. Vairākums ārstu, vai 91,6 \% (n = 198) uzskata, ka depresijas skrīnings Latvijā ir nepieciešams. Kaut arī 62,6\% $(\mathrm{n}=135)$ ǵimenes ārstu uzskata, ka vinuu prakses ir labi piemērotas depresijas pacientu aprūpei, puse no dalībniekiem, vai 50,9\% $(\mathrm{n}=110)$ vērtē savas spējas veidot uzticamu kontaktu un motivēt pacientu ārstēties kā viduvējas. Kaut arī gimenes ārsti atzīst depresijas ārstēšanas nozīmi un nepieciešamību, esošās zināšanas un pieejas slimības aprūpei ir tālas no optimālajām. Tas pamato speciālo apmācības programmu nepieciešamību. 